\title{
Competitive Advantage Achievement through Innovation and Knowledge
}

\section{Urbancová Hana}

\begin{abstract}
In today's highly competitive environment the goal of each organisation is to defeat competition and win new customers. Individuals who are holders of knowledge represent a tool for the generation of innovations. Thanks to their personal creativity, their knowledge, skills and abilities it is possible to generate new innovative ideas that will help organisations to achieve a competitive advantage. The aim of the article is to present the findings of a survey targeted at innovations and to identify knowledge as an important element in the process of innovations. Primary data were obtained through a questionnaire survey carried out in organisations in the Czech Republic and evaluated using the tools of descriptive statistics and also the methods of comparison, induction, deduction and synthesis were applied. One of the conclusions of the article is that organisations find it important to innovate and support an innovative culture. Knowledge too is very significant in the innovation process since it represents not only important input, but also output of the transformation process.
\end{abstract}

Key words: knowledge, innovation, competitive advantage, organisations, questionnaire survey

\section{INTRODUCTION}

Authors (Bartes, 2009; Hamel \& Green, 2007; Senge, 2007; Barták, 2006; Collinson, 2005) agree that the 21 st century is based on knowledge, information and innovative economy. Organisations' success depends on employees' knowledge, experience, creative activity and qualification and emphasis is placed on continuous learning and research and development.

Already in 1986 Tushman \& Nadler stressed that "organisations can gain competitive advantage only by managing effectively for today while simultaneously creating innovation for tomorrow" and suggested that "there is perhaps no more pressing managerial problem that the sustained management of innovation". Tushman \& Nadler (1986) identify visionary leadership and also people, structures and values as important factors that affect whether an organisation realizes benefits from innovation. Innovation is still seen as a critical drive of economic performance.

In this respect, education has been pointed out as a key aspect for the economic success of the every organisations (Romero \& Martinez-Roman, 2012; Kangasharju \& Pekkala, 2002). Since knowledge is a fundamental factor in the innovaton and assimilation of new technologies (Romero \& Martinez-Roman, 2012; Hoffman et al., 1998), individual training plays an important role contributing to the internal learning and the generation of new ideas within the business (Galende \& De la Fuente, 2003). The education background of the managers, business owners and entrepreneurs has been found to be an important factor explaining innovation in organisations (Koellinger, 2008). The research shows (Romero \& Martinez-Roman, 2012; Romero, 2009) that the organisational taking part in value chains could stimulate their processes of inno- 
vation and technological improvement by the spill over of knowledge and demands from larger organisations, while others consider that this possibility has been overestimated. On the other hand, business cooperation can be an important route for the transmission of the knowledge and experience in the production network. This is even more important in the case of small organisations because, in comparison to large organisations, they have a reduced innovative autonomy and they do not usually collaborate with technological centers (Romero \& Martinez-Roman, 2012; Dyer \& Singh, 1998). Based on the above it can summarize that innovative projects and competitive advantage of these organisations are dependent on the goal of sharing resources and knowledge.

The paper presents the results of the research focused on innovation and discusses the importance of knowledge in the area of innovation. The paper was based on the evaluation of quantitative research. The first part contains the theoretical background which presents the author's views on this area and the results of the foreign research. The next chapter contains the objective of the paper and describes the methodology of the survey according to which was processed, analyzed and evaluated obtained primary data. The chapter Results is divided into the four parts which focus on summarizing the results of survey in the Czech Republic, the evaluation of results, the verification of results and on the importance of knowledge in the innovation process. The chapter discussion and conclusion includes the summary and specifies the preconditions to gain innovativeness in the organisation.

\section{THEORETICAL BACKGROUND OF THE WORK}

The term "innovation" as such was used for the first time by Schumpeter at the beginning of the 20th century. His ideas and research have been developed by a number of other authors. Schumpeter defined innovations as product, process and organisational changes that do not necessarily originate from new scientific discoveries (Žižlavský, 2011), but may arise from a combination of already existing technologies and their application in a new kontext (Žižlavský, 2011). Innovation also originates from public research (Autant-Bernard, 2001). It is therefore possible to summarise that according to these definitions innovations do not cover only technical and technological changes and improvements, but in particular practical application and particularly originates from research.

Human capital and creative research work are according to Zemplinerová (2010) and AutantBernard (2001) considered the most important determinants of innovation. Adair (2004) states that any innovative organisation should have a bucketful of ideas. According to Košturiak \& Chal' (2008), Skarzynski \& Gibson (2008), Tidd, Bessant \& Pavitt (2007) an innovative process can be divided into two essential parts. One part is inventive - associated with the generation of the original idea, thought or concept - and the second innovative, during which the invention is implemented and marketed. Pitra (2006) states that innovation is the result of employees' creativity in an organisation and must be always targeted at customers and bring added value. It is therefore necessary to realise that the inventive part is based on people's knowledge, skills and experience (Molina-Morales, Garcia-Villaverde \& Parra-Requena, 2011). The human factor is an indispensable element in the process of innovation. Based on analyses of external end internal conditions, people generate ideas that might help an organisation gain a competitive advantage 
and thus distinguish it, at least for a certain period of time, from its competitors. Innovation capability of an organisation according to Martín-de Castro, Delgado-Verde, Navas-López \& Cruz-González (2013) depends closely on its intellectual and/or organisational knowledge assets and on its ability to employ these assets. Noruzy, Dalfard, Azhdari, Nazari-Shirkouhi \& Rezazadeh (2012) reasearches showed that organisational learning and knowledge management directly influenced organisational innovation, whereas organisational learning and organisational innovation directly influenced organisational performance.

According to Tidd et al. (2006) innovation contributes to achieving a competitive advantage in several aspects. The most important characteristics of innovations include:

- A strong relationship between market performance and new products.

- New products help maintain market shares and improve profitability.

- Growth also by means of non-price factors (design, quality, individualisation, etc.).

- Ability to substitute outdated products (shortening product lifecycles).

- Innovation of processes that lead to production time shortening and speed up new product development in comparison to competitors.

Martín-de Castro et al. (2013) say that developing successful technological innovations is essential for creating and sustaining an organisation's competitive advantage. According to Zemplinerová (2010) the expenditures on research, development and introduction of innovations are the determining characteristics for gaining a dominant part of the market. Autant-Bernard, Fadairo \& Massard (2013) in their survey also show the importance of the role of the regional innovation and they argue that organisation must have original strategies and support the knowledge flows from and to organisation. It is supported by results of Noruzy et al. (2012) and Autant-Bernard (2001).

The above shows that the innovative activity of organisations significantly influences competitiveness which is based on inimitable skills and abilities. Achieving a higher competitiveness by means of innovations means producing less costly products of better quality compared to those manufactured by competitors.

If an organisation is not capable of introducing innovations on an ongoing basis, it risks that it will lag behind and the initiative will be taken over by other entities. Schumpeter (in Tidd et al., pp. 8, 2006) asserts that entrepreneurs attempt to use technological innovation - a new product or service or perhaps a new process in the course of their production - provided they thus gain a strategic competitive advantage. This creates competition that does not attack profit margins or the outputs of existing organisations, but their essence and their existence as such.

With respect to the above said it is important - within the frame of innovations - that are a necessity in today's knowledge, information and innovative society - to follow large organisations that engage in innovation and set the direction for others (Zemplinerová, 2010). The present concept of innovations is that they represent an open approach that reaches beyond the threshold of an organisation and thus exploits not only inspections and changes in the internal environment, but also changes in the external environment. The internal environment of an organisation needs to have a suitably preset innovative culture, since this type of culture is characterised by the transience of organisational structures, utilisation of specialists and temporary teams, mobile offices, the necessity of speedy and flexible changes responding to new opportunities, which increases 
the innovative potential of such organisations (Molina-Morales et al. (2011)). There is no place for standardisation; each project is unique. Its characteristic features include flexibility, openness to changes, searching for information and resources in the external environment, anticipation, creativity, experimenting and informal communication. Checks in organisations with this type of culture are not necessary and in order to maintain consistency between managerial practices and the content of such culture it is actually impossible - good work is associated with loyalty arising from the engagement of employees in the fulfilment of the organisation's goals and performance of their tasks (Lukášová, 2010).

\section{OBJECTIVE AND METHODOLOGY}

The aim of the article is to present the outcomes of a survey targeted at innovation issues. A partial goal is to identify knowledge as an important element in the process of innovation and to test dependencies between the preset quantitative elements.

In order to meet the goal of the project, an analysis of secondary resources has been carried out which generated a list of theoretical points of departure related to the topic. The article has been drawn up using scientific methods, in particular logical methods, such as analysis, synthesis, induction and deduction. Moreover, a primary survey has been conducted focusing on the level of innovations in organisations in the Czech Republic, with emphasis on knowledge which is an essential factor of the process in question.

Primary data targeted at innovation, innovation culture and knowledge was obtained by means of a quantitative survey using a questionnaire technique of data collection. Organisations that took part in the survey were selected by random quota sampling from organisations presented on Internet and actively participating organisations. The organisations were divided into the homogeneous groups according to the selection criterias (sector and size of organisation) and their managers were addressed in order to form a sample whose structure corresponded to the structure of organisations in the Czech Republic according to the Czech Statistical Office (2012). The questionnaire survey took place in the period from 10/2011 to 6/2012 and a total of 109 organisations undertaking their activities in the territory of the Czech Republic were involved. The structure of organisations aimed at innovation, innovation culture and knowledge in the period 2011 - 2012 was as follows:

- According to the business sector: private: $71.6 \%$ of organisations, public: $28.4 \%$ of organisations

- According to the size (number of employees): small businesses: $49 \%$, mid-sized businesses: $29 \%$, large businesses: $22 \%$ (small: up to 50 employees, mid-sized: $50-249$, large: $250+$ ).

The questionnaire had 12 questions on the research topic and 4 identification questions (business sector of economy, size of organisations, branch of business). The most $29 \%$ organisations work in services, $16 \%$ in industry, $12 \%$ in civil engineering and $9 \%$ work in banking. A total of 189 organisations were contacted. The overall questionnaire return was $58 \%$, i. e. 109 organisations took part. The questionainnaire completed managers these organisations on the middle and top management by email. The formulation of questions has arised from co-operation with School of Economics and Management in Public Administration in Bratislava. In the questions there were used specialist terms generally known for middle and top managers. For questions that could lead to the ambiguous understanding the term was explicitly defined. 
To evaluate the results, methods of descriptive statistics were used (statistical software SPSS 19); absolute and relative frequencies, testing of dependency between set qualitative features and dependency tests. The analysis was carried out using the Microsoft Excel 2007 and SPSS programmes.

\section{RESULTS}

The chapter presents and evaluates the outcomes of the questionnaire survey on the area of innovation in the Czech Republic. Individual chapters focus on the testing of hypotheses relating to individual survey questions.

\subsection{Results of survey focused on innovation in organisations}

Based on the data obtained from the quantitative survey and its evaluation, it is possible to state that at present organisations find it important to concentrate on innovation. Only $5.5 \%$ of organisations mentioned that they did not find this aspect important. Representatives of these organisations also added that it was difficult for them to innovate as it was a demanding task and they did not have the possibility to hire (for financial reasons) specialists to help them deal with it. For detailed results see Table no. 1.

Tab. 1 - The importance of innovation for organisations. Source: own elaborate (data Urbancová, Königová, 2012)

\begin{tabular}{|c|c|c|}
\hline $\begin{array}{c}\text { Is it innovation important } \\
\text { for your organisation? }\end{array}$ & Absolute frequencies & Relative frequencies \% \\
\hline YES & 103 & 94,5 \\
\hline NO & 6 & 5,5 \\
\hline
\end{tabular}

With respect to the fact that a vast majority of organisations find innovations in current conditions to be a necessity, the survey also focused on the issue of innovative culture and whether it was important for organisations to establish a suitable innovative culture that would support innovations in organisations. The results are shown in Table no. 2.

Tab. 2 - The importance of innovation culture in organisations. Source: own elaborate (data Urbancová, Königová, 2012)

\begin{tabular}{|c|c|c|}
\hline $\begin{array}{c}\text { Is it important to have a suitable } \\
\text { innovation culture in organisation? }\end{array}$ & Absolute frequencies & Relative frequencies \% \\
\hline YES & 89 & 81,7 \\
\hline NO & 20 & 18,3 \\
\hline
\end{tabular}

Almost $82 \%$ of respondent organisations stated that it was important to have a suitable innovative culture; only $18.3 \%$ of organisations did not share this opinion. Respondents most often mentioned that an innovative culture in organisations contributes to increasing their innovative potential, for example leads to a competitive advantage (29.8\%), an organisation's development $(19.3 \%)$, a higher efficiency of processes $(3.5 \%)$ and a higher profit $(3.5 \%)$. A total of 20 or- 
ganisations mentioned that there was no need for developing a suitable innovative culture; most frequently they added that their employees were busy and that the organisation's size played an important role.

Only 26 organisations out of the organisations that consider innovative culture important have such culture established (29\%). The majority of organisations feel that it is important, but unfortunately have not established it yet $(70.5 \%)$. The most frequent reasons are that these organisations innovate without establishing an innovative culture or they do not find it necessary for the innovative process as such (14.1\%). $12.8 \%$ of organisations stated that it was too costly for them and 2 respondents did not comment on this. Organisations that have already established an innovative culture usually introduced it in 2010, following the economic crisis $(36.8 \%)$.

The most common impulses for innovation are those provided by large customers ( $90.8 \%$ ), suppliers $(80.7 \%)$ and employees $(65.1 \%)$. The list of impulses for innovation mentioned by organisations are shown in Table no. 3 (in relative frequencies).

Tab. 3 - The most frequent impulse to innovation organised by relative frequencies.

Source: own elaborate (data Urbancová, Königová, 2012)

\begin{tabular}{|l|c|c|}
\hline Impulse from: & YES & NO \\
\hline big customers & 90,8 & 9,2 \\
\hline Suppliers & 80,7 & 19,3 \\
\hline Employees & 65,1 & 34,9 \\
\hline Customers & 59,6 & 40,4 \\
\hline Competitors & 40,4 & 59,6 \\
\hline Experts & 40,4 & 59,6 \\
\hline own survey & 7,3 & 92,7 \\
\hline collaboration with universities & 7,3 & 92,7 \\
\hline Other & 1,8 & 98,2 \\
\hline
\end{tabular}

\subsection{Evaluation of the results}

Contingency tables that determine dependencies between identified qualitative features have been prepared based on the absolute and relative frequencies obtained from the questionnaire survey. Relevant boxes of the contingency table state the numbers of cases when the first feature (importance of innovation or importance of an innovative culture) also demonstrated the value corresponding to the relevant line (yes, no) and the second feature the value corresponding to the relevant column (organisation's size or economic sector). Individual dependencies are then tested using Pearson's Chi-Square Test; see Chapter 4.3.

Table No. 4 shows dependencies between the importance of innovations and an organisation's size (in absolute frequencies). The results reveal that small organisations with up to 50 employees consider innovations to be the most important (49.5\%); they are followed by middle-sized and large organisations. For only less than $6 \%$ of organisations, mostly mid-sized ones, innovations are not important according to their representatives. 
Tab. 4 - Contingency table between qualitative characteristics. Source: own elaborate (data Urbancová, Königová, 2012)

\begin{tabular}{|c|c|c|c|c|c|}
\hline \multirow{2}{*}{ Question } & \multicolumn{3}{c|}{ Size of organisation } & \\
\cline { 2 - 6 } & $\begin{array}{c}\text { Under } 50 \\
\text { employees }\end{array}$ & $\begin{array}{c}51 \text { to } 249 \\
\text { employees }\end{array}$ & 250 and more & Total \\
\hline $\begin{array}{c}\text { Is it innovation } \\
\text { important for your } \\
\text { organisation? }\end{array}$ & YES & 51 & 28 & 24 & 103 \\
\cline { 2 - 6 } & NO & 2 & 4 & 0 & 6 \\
\hline
\end{tabular}

Based on the results it may be concluded that all organisations think that innovations and innovative activities are important. It is possible to say that both small and large organisations generally follow the same goals in the area of innovative activities. All organisations, regardless of their size, strive to obtain, by means of successful innovations, a significant and, if possible, longterm and sustainable competitive advantage and finally convert it into better financial results. At present, any organisation that wishes to maintain its position in the market has to innovate.

From the specific point of view, innovations in small and large organisations are totally different (which is confirmed by the surveys conducted; see Rothwell et al. (1994) and Hoffman et al. (1998)). Small organisations have the advantage of flexible decision-making and the ability to adapt; however, compared to large organisations, they do not have sufficient resources necessary for innovation implementation.

Absolute frequencies shown in Table no. 5 reveal that the majority of respondent organisations from the private sector $(96 \%)$, like those from the public sector $(90 \%)$, see the importance of innovations in the current competitive environment. Only 3 organisations in the private (4\%) and public sectors $(10 \%)$ do not consider innovations important.

Tab. 5 - Contingency table between qualitative characteristics. Source: own elaborate (data Urbancová, Königová, 2012)

\begin{tabular}{|c|c|c|c|c|}
\hline \multirow{2}{*}{\multicolumn{2}{|c|}{ Question }} & \multicolumn{2}{c|}{ Sector of economy } & \multirow{2}{*}{ Total } \\
\cline { 3 - 5 } & Private & Public & \\
\hline \multirow{2}{*}{$\begin{array}{c}\text { Is it innovation important } \\
\text { for your organisation? }\end{array}$} & YES & 77 & 26 & 103 \\
\cline { 2 - 5 } & NO & 3 & 3 & 6 \\
\hline
\end{tabular}

It is necessary to say that both the private and public sectors have a different approach to innovations and support for an innovative culture. Currently the EU tends to support the co-operation between the public and private sectors, this, however, triggers a number of difficulties, such as insufficient organisations' facilities, an insufficient transfer of knowledge and technologies, etc. These differences are even more evident if we take into consideration a division into primary, secondary and tertiary sectors. This is further confirmed by the results of surveys conducted by Tether (2004) which show that innovative organisations in the tertiary sector focus primarily on the introduction of organisational changes, while the secondary sector is predominated by product and process innovations. 
Absolute frequencies in Table no. 6 show that establishing a suitable innovative culture is important for the majority of respondent organisations (86\%), in particular for the large ones $(96 \%)$, followed by mid-sized (88\%) and small organisations (81\%). Small organisations, compared to large ones, are more based on traditions and past experience and do not need to have the areas of innovative culture explicitly defined. On the contrary, large organisations give preference to the identification and establishment of a suitable innovative culture and require that it is accepted by all employees of the organisation.

Tab. 6 - Contingency table between qualitative characteristics. Source: own elaborate (data Urbancová, Königová, 2012)

\begin{tabular}{|c|c|c|c|c|c|}
\hline \multirow{2}{*}{\multicolumn{2}{|c|}{ Question }} & \multicolumn{3}{c|}{ Size of organisation } & \multirow{2}{*}{ Total } \\
\cline { 2 - 6 } & $\begin{array}{c}\text { Under } 50 \\
\text { employees }\end{array}$ & $\begin{array}{c}51 \text { to } 249 \\
\text { employees }\end{array}$ & 250 and more & \\
\hline \multirow{2}{*}{$\begin{array}{c}\text { Is it important to have } \\
\text { a suitable innovation } \\
\text { culture in organisation? }\end{array}$} & YES & 43 & 28 & 23 & 94 \\
\cline { 2 - 6 } & NO & 10 & 4 & 1 & 15 \\
\hline
\end{tabular}

Also the majority of respondent organisations from the private sector $(85 \%)$ and from the public sector $(90 \%)$ stated that for innovations to be successful it was necessary to have an innovative culture established. Only 9 organisations mentioned that innovations were important for them, but they did not consider it important to have an innovative culture established within their organisation. Respondents from the public sector agreed that the success of innovations was related to a suitably established innovative culture within an organisation. Detailed results are shown in Table no. 7 (in absolute frequencies).

Tab. 7 - Contingency table between qualitative characteristics. Source: own elaborate (data Urbancová, Königová, 2012)

\begin{tabular}{|c|c|c|c|c|}
\hline \multirow{2}{*}{ Question } & \multicolumn{2}{c|}{ Sector of economy } & \multirow{2}{*}{ Total } \\
\cline { 3 - 5 } & Private & Public & \\
\hline $\begin{array}{c}\text { Is it important to have a } \\
\text { suitable innovation culture } \\
\text { in organisation? }\end{array}$ & YES & 68 & 26 & 94 \\
\cline { 2 - 5 } & NO & 12 & 3 & 15 \\
\hline
\end{tabular}

Based on the results obtained and on the comparison with similar surveys, such as that conducted by Hoffman et al. (1998), it has been determined that the two most important internal factors that significantly influence innovative activities in organisations are employee qualifications and strong leadership. It is necessary to say that according to the surveys the majority of small organisations implement innovative management solely intuitively, without taking deliberate steps and without having a sufficient number of qualified employees, which in turn leads to a failure of the given innovation. On the contrary, large organisations take advantage of their resources, whether they are of a financial or technological nature or regard the use of specialists and professional management, etc. 


\subsection{Verification of the results}

Based on the dependency between the studied qualitative characteristics in the chapter 4.2 two null hypothesis about absence of dependence were made. Using extracted data there was tested a dependency by applying of Pearson's Chi-Square test. If the p-value calculated by means of the $\chi^{2}$ test (Pearson Chi-Square) was lower than the selected level of significance $\alpha=0.05$, null hypothesis was rejected.

The survey tested the two hypotheses specified:

\section{$\mathrm{H}_{0}$ 1: Application of innovation culture does not depend on the sector of the economy. $\mathbf{H}_{0}$ 2: Application of innovation culture does not depend on the size of the organisation.}

The dependency between the application of innovation culture and sector of the economy is not statistically important at the $5 \%$ significance level. P-value is 0.596 and it is higher than $\alpha$. The dependency between the applications of innovation culture and size of the organisation is not statistically important too at the 5\% significance level. P-value is 0.446 and it is higher than $\alpha$. Therefore the both null hypotheses cannot be rejected.

Nevertheless there must be taken into account the results of similar surveys focused on whether innovative culture in organisations directly influences the economic success of organisations and whether innovative strategy is a factor that determines competitiveness (Martín-de Castro et al., 2013) (survey in 251 organisations), Noruzy et al. (2012)(survey in 106 organisations), Molina-Morales et al. (2011) (survey in 224 organisations) and also survey Kachaňáková, Stachová, Stacho (2012) (survey in 340 organisations) in Slovak Republic where dependency between innovation culture and sector of the economy was proven, and also the research of Zemplinerová (2010) where the dependency between innovation culture and both size and sector of the organisation was proven.

These results indicate, that dependencies between innovation culture and both sector and size of organisation may still be expected.

According to the survey, the main advantages of an innovative culture include: improved products for customers, getting ahead of competitors, higher efficiency of funds invested into innovations and in particular providing space to people with a high potential and maintaining of employees who would otherwise leave to join a competitor or to found their own organisation.

\subsection{Importance of knowledge in the innovation process}

By summarising the theoretical background of the work, it is necessary to realise that successful innovations are never a one-off event, but a result of a long-term process in which the human factor plays and important role.

Innovations can only turn out to be successful if they are supported by top management and if an innovative creative team is developed and composed of people that may be considered knowledge employees. An innovative team should be a natural point around which the key employees of the organisation are gathered since the concentration of know-how in a team and its development have a major impact on innovations in the entire organisation. These members of the team create the core of innovations that undoubtedly supports the innovative culture of the organisation simply by the fact that they share their knowledge on innovation implementation with the rest of the employees (teach them). An advantage of these employees heading for a successful 
innovation is the knowledge of the innovative process and tools and the exploitation of their experience. It is necessary to take into account that the innovation process efficiency is dependent on previous experience with and knowledge of the process of innovation and the ability to avoid obstacles that innovations bring along.

The knowledge already acquired helps us understand connections between new pieces of information. Each of the following processes may thus be quicker and more efficient as more information means more patterns for information processing. Knowledge itself, however, is not sufficient for a perfect understanding of the problem and finding new solutions. It is important to say that it helps to process the gathered information well; however, it does not create a sufficient base for creativity.

In order to determine dependencies between the importance of innovations and knowledge sharing by employees, contingency Table no. 8 has been developed. The results reveal that $80 \%$ of organisations that find it important to focus on innovations also support knowledge and experience sharing by current employees. Only $20 \%$ of respondent organisations confirmed that innovations were important for them, however, they did not support knowledge sharing that would contribute to innovations.

Tab. 8 - Contingency table between qualitative characteristics. Source: own elaborate (data Urbancová, Königová, 2012)

\begin{tabular}{|c|c|c|c|c|}
\hline \multirow{2}{*}{ Question } & \multicolumn{2}{c|}{ Knowledge sharing } & \multirow{2}{*}{ Total } \\
\cline { 3 - 5 } \multicolumn{2}{|c|}{} & YES & NO & \\
\hline $\begin{array}{c}\text { Is it innovation important for your } \\
\text { organisation? }\end{array}$ & YES & 82 & 21 & 103 \\
\cline { 2 - 5 } & NO & 4 & 2 & 6 \\
\hline
\end{tabular}

A total of $25 \%$ of respondent organisations stated that knowledge was shared by colleagues on a long-term basis and that they created so-called knowledge bases (they recorded knowledge and previous experience) that helped employees implement innovations. 34\% took advantage of this only on a random basis and in a short-time horizon while the majority of organisations (41\%) did not exploit this possibility at all (see Table no. 9).

Tab. 9 - Contingency table between qualitative characteristics. Source: own elaborate (data Urbancová, Königová, 2012)

\begin{tabular}{|c|c|c|c|c|c|}
\hline \multirow{2}{*}{\multicolumn{2}{|c|}{ Question }} & \multicolumn{3}{c|}{ Using knowledge base } & \multirow{2}{*}{ Total } \\
\cline { 3 - 6 } \multicolumn{2}{c|}{} & $\begin{array}{c}\text { YES long } \\
\text { term }\end{array}$ & $\begin{array}{c}\text { YES short } \\
\text { term }\end{array}$ & NO & \\
\hline \multirow{2}{*}{$\begin{array}{c}\text { Is it innovation important } \\
\text { for your organisation? }\end{array}$} & YES & 26 & 35 & 42 & 103 \\
\cline { 2 - 6 } & NO & 0 & 2 & 4 & 6 \\
\hline
\end{tabular}

The findings presented confirm that knowledge is important for innovations and contributes to the success of innovations implemented. The most of managers of organisations said that knowledge and work with them project into the improved innovation activities. The most often it is creating new market opportunities (17\%). For the evaluation of the results has been also used 
a parametric test for determine the dependency between two independent sets, i. e. the comparison of category of benefits in terms of innovation (improving research and development, application of new technologies, new products and services, new business segments) and the size of the organisation. For the evaluation there was used the Kruskal-Wallis test to identify that in each category "Innovation" there is no statistically significant difference among the benefits occurring in small, medium and large organisations.

According to the results of surveys conducted by Romero and Martinez-Roman (2012), other features that influence innovations are: education, experience, internal motivation, stimulation, the size of the organisation and the economic sector.

On the basis of the findings it is possible to summarise and recommend that the so-called intelligent growth strategy be supported. It is one of the pillars of the Europe 2020 strategy which is based on knowledge and innovations and it places emphasis on an uninterrupted and continuous process of learning. As Světlík adds (2008), the innovative process may be seen as having four major stages, which are as follows: invent - develop - produce - sell or, in other words, "Science turns money into knowledge and innovations turn knowledge into money". Therefore knowledge is very important in the process of innovations and represents not only valuable input, but also output from the transformation process.

\section{DISCUSSION}

Small and mid-sized organisations belong among the most significant entities of the Czech economy. According to the data of the Czech Statistical Office, they account for $99.85 \%$ of all entities operating in the Czech Republic. They provide jobs to more than $60 \%$ of all employees and generate approximately one third of the gross domestic product. They export around one half of all goods and services. With respect to the above said it might be stated that these organisations have to be potential innovators to maintain their position in the market.

Value-generating processes in small organisations are as complex as those applied by middlesized or large organisations, in particular as far as production is concerned. The difference is, however, in resources, in particular financial resources. Other limitations are in the area of personnel arrangements. Employees at the level of top and higher management often are not substitutable and also for a number of roles the relevant substitutability is missing.

Public and private sector partnerships can contribute to economic recovery and sustainable growth of the European Union (EU). The interconnection of public and private capacities and funds is essential in the context of economic crisis. The Commission creates barriers in the process of their establishment and ensuring funds to support such partnerships. The aim of the Union of Innovations is to focus on the above-mentioned challenges - not only within the European Union, but also in co-operation with third countries. Impulses from the public sector will motivate the private sector and eliminate barriers that prevent new ideas from being implemented and marketed, for example, due to the shortage of financial means, fragmented research structures and markets, an insufficient use of public tenders for innovations and a lengthy process of new standard implementation.

On the basis of the evaluation of the results of the survey targeted at innovations in organisations in the Czech Republic, it is possible to state that without the right people with knowledge 
and experience it is impossible to achieve the required level of innovations. The conclusions of this article may be supported by the findings of the survey conducted by Romero and MartinezRoman (2012) which determine these factors as essential and add other factors, such as motivation, finance and support of top management.

As mentioned in the conclusions of the survey conducted by the Technology Transfer Institute of the Tomas Bata University in Zlín and the Technological Centre of the Academy of Sciences of the CR entitled "Developing Knowledge for New Innovations", it is impossible to succeed in today's world without permanent development of knowledge, skills and abilities.

It is also possible to state that starting from the 1990s the social paradigm has been undergoing changes and the industrial society has been transforming into a knowledge society. Capable employees who create conditions for differentiation from competitors become a key resource for organisations. These employees are the most essential resource for gaining innovative abilities by an organisation. To create an innovative environment within an organisation, it is not sufficient to establish a research and development department, the right thing would be to provide each employee with time for creative self-realisation. The main task of managers should therefore be to support individual initiatives and creativity of individual employees. It is also possible to say that innovativeness founded on knowledge and the ability to respond to a turbulent environment is perceived as a source of profitability and success of organisations in the present competitive environment.

To gain right innovativeness of the organisation the following preconditions should be fullfilled:

- to develop an appropriate innovative culture in the organisation and to support a continuous innovation,

- to strengthen the innovative potential by linking the existing fragments of knowledge resources and to create new markets,

- to effectively use the potential of knowledge workers in the organisation by practical realization of their ideas,

- to stimulate individual ideas and to motivate staff to trust the leaders to come up with new ideas,

- to group managers and specialists with a different specialisation from the external and internal environment of the organisation in order to generate new ideas,

- to continuously support and to motivate small and medium organisations which form the largest group of innovators.

\section{CONCLUSION}

Based on the evaluation of the outcomes obtained in organisations in the Czech Republic, it is possible to summarize that:

- The importance of innovations and necessary knowledge is generally identical for all organisations, regardless of their size and economic sector; the survey has shown that the majority of large and small organisations place emphasis on innovations and establishing a suitable innovative culture. 
- Innovations are a key source of a competitive advantage that determines the economic success of each organisation.

- If organisations wish to survive and grow in today's turbulent environment, they have to make every effort to introduce an innovative approach and creativity; therefore top management's support is essential.

- In the process of innovation, knowledge is an essential element and in the present competitive environment innovations help gains an advantage over other organisations. The majority of respondent organisations that participated in the survey stress the importance of knowledge and experience sharing by current employees that encourage the success of innovations.

To conclude, it is possible to state that innovations are and will surely continue to be a means for organisations to survive in today's turbulent and highly competitive environment.

\section{Acknowledgement}

This contribution is a follow-up to the project of the Czech University of Life Sciences Prague, University - wide internal grant agency (CIGA), number 20121001 - Business continuity management contributing to higher performance in organisations. Data from the survey from Slovak Republic was designed in co-operation with the Department of Management at School of Economics and Management in Public Administration in Bratislava (SEMPA).

\section{References}

1. Adair, J. (2004). Efektivní inovace. Praha: Alfa.

2. Autant-Bernard, C. (2001). Science and knowledge flows: Evidence from the French case. Research Policy, 30(7), 1069-1078. http://dx.doi.org/10.1016/S0048-7333(00)00131-1

3. Autant-Bernard, C., Fadairo, M. \& Massard, N. (2013). Knowledge diffusion and innovation policies within the European regions: Challenges based on recent empirical evidence. Research Policy, 42 (1), 196-210. http://dx.doi.org/10.1016/j.respol.2012.07.009

4. Barták, J. (2006). Skryté bohatstuí firmy. Praha: Alfa.

5. Bartes, F. (2009). Paradigma inovací a hodnotové inž̌nýrství. Brno: VÚT.

6. Collison, Ch. (2005). Knowledge management. Brno: Computer Press.

7. Dyer, J. H. \& Singh, H. (1998). The relational view: cooperative strategy and resources of interorganizational competitive advantage. Academy of Management Review, 23(4), 660-679. http://dx.doi.org/10.2307/259056

8. Galende, J. \& De la Fuente, J. (2003). Internal factors determining a firmś innovative behaviour. Research Policy, 32(5), 715-736. http://dx.doi.org/10.1016/S0048-7333(02)00082-3

9. Hamel, G. \& Green, B. (2007). The Future of Management. Boston: Harvard Business School Press.

10. Hoffman, K., Parejo, M., Bessant, J. \& Perren, L. (1998). Small firms, R\&D, technology and innovation in the UK: A literature review. Technovation, 18(1), 39-55. http://dx.doi. org/10.1016/S0166-4972(97)00102-8

11. Kangasharju, A. \& Pekkala, S. (2002). The role of education in self-emplyment success in Finland. Growth and Change, 33(2), 216-237. http://dx.doi.org/10.1111/0017-4815.00188 
12. Košturiak, J. \& Chal', J. (2008). Inovace: Vaše konkurenční výhoda. Brno: Computer Press.

13. Lukášová, R. (2010). Organizační kultura a její żmèna. Praha: Grada Publishing, s. 240.

14. Pitra, Z. (2006). Management inovačních aktivit. Praha: Professional Publishing.

15. Koellinger, P. (2008). Why are some entrepreneurs more innovative than others? Small Business Economics, 31(1), 21-37. http://dx.doi.org/10.1007/s11187-008-9107-0

16. Martín-de Castro, G., Delgado-Verde, M. Navas-López, J. E. \& Cruz-González, J. (2013). The moderating role of innovation culture in the relationship between knowledge assets and product innovation. Technological Forecasting and Social Change, 80(2), 351-363. http:// dx.doi.org/10.1016/j.techfore.2012.08.012

17. Molina-Morales, F. X., Garcia-Villaverde, P. M. \& Parra-Requena, G. (2011). Geographical and cognitive proximity effects on innovation performance in SMEs: a way through knowledge acquisition. International Entrepreneurship and Management Journal, 1-21. http:// dx.doi.org/10.1007/s11365-011-0214-z

18. Noruzy, A., Dalfard, V. M., Azhdari, B., Nazari-Shirkouhi, S. \& Rezazadeh, A. (2013). Relations between transformational leadership, organizational leasing, knowledge management, organizational innovation and organizational performance: an empirici investigation of manufactruing firms. The International Journal of Advanced Manufacturing Technology, 64(5-8), 1073-1085. http://dx.doi.org/10.1007/s00170-012-4038-y

19. Romero, I. (2009). PYMES y cadenzas de valor globales. Implicacioness para la politica industrial en las economias an desarrollo. Análissis Económico, 24(57), 199-216.

20. Romero, I. \& Martine-Roman, J. A. (2012). Self-employment and innovation. Exploring the determinants of innovative behaviour in small business. Research Policy, 41(1), 178-189. http://dx.doi.org/10.1016/j.respol.2011.07.005

21. Rothwell, R. \& Dodgson, M. (1994). Innovation and Size of Firm. The Handbook of Industrial Innovation. Aldershot: Edward Edgar Publ.

22. Senge, P. (2007). Pátá disciplina - Teorie a praxe učicí se organizace. Praha: Management Press.

23. Skarzynski, P. \& Gibson, R. (2008). Innovation to the Core: A Blueprint for Transforming the Way Your Company Innovates. Boston: Harvard Business School Press.

24. Světlík, J. Věda dělá zpeněr znalosti a inovace dělaji ze znalostípeníze [online] Retrieved from: http://www.vitkovice.cz/default/file/download/id/2024/inline/1>.

25. Tether, B. (2004). Do Services Innovate (Differently)? CRIC Discussion Paper, 66, Manchester, Centre for Research on Innovation \& Competition.

26. Tidd, J., Bessant, J. \& Pavitt, K. (2007). Řizení inovací - zavádèní technologickéch, tržñich a organizačnich změn. Brno: Computer Press.

27. Tushman, M. \& Nadler, D. (1986). Organizing for innovation. California Management Review, 28(3), 74-92. http://dx.doi.org/10.2307/41165203

28. Zemplinerová, A. (2010). Inovační aktivita firem a konkurence. Politická ekonomie, 58(6), 747-760.

29. Žižlavský, O. (2011). Zapojení zákazníků do inovačního procesu jako prostředek vedoucí ke zvyšování výkonnosti podniku. Journal of Competitiveness, 3(1), 15-24. 


\section{Contact information}

Ing. Hana Urbancová, Ph.D.

Czech University of Life Sciences Prague, Faculty of Economics and Management

Department of Management

Kamýcká 129, 16521 Prague 6 - Suchdol

Crech Republic

Tel.: +420224382026

E-mail:urbancova@pef.czu.cz.

JEL Classification: O3, D83 